\title{
Making Sense of Citizen Mobilizations against the Trump Presidency
}

\author{
Theda Skocpol
}

\begin{abstract}
The Resistance: The Dawn of the Anti-Trump Opposition Movement. Edited by David S. Meyer and Sidney Tarrow. New York: Oxford University Press, 2018. 358p. \$99.00 cloth, \$24.95 paper.
\end{abstract}

$\square$ onald Trump's 2016 Electoral College victory shocked most pundits and politicians - and this president's time in office has proved even more chaotic and disruptive than most expected. Day-to-day news seeks to unpack often-disturbing or confusing maneuvers in Washington, DC. Yet during the rise and reign of Trump, much more important and highly contentious civic and political shifts are playing out on the national stage.

Protests against Trump's persona, policies, and very legitimacy started right after election day and reached an early climax in massive postinaugural Women's Marches involving more than four million Americans parading in more than 600 locales. More protests ensued, even as thousands of local volunteer citizen groups formed to change the politics of health reform, generate a flood of new Democratic candidates, and buoy voter turnout in 2017 special contests and the 2018 midterms.

Fast-moving events are challenging for scholars to conceptualize and measure. Yet two years into the Trump-GOP era, important studies are appearing including this collection on many aspects of the antiTrump civic resistance edited by David S. Meyer and Sidney Tarrow. One chapter in the book, by Kenneth Roberts, offers valuable cross-national comparisons of "exclusionary populist politics," highlighting the ways distinctive U.S. governmental institutions and partisan politics enabled Trump's victory and shaped opposition to his presidency. But most of the chapters focus on antiTrump mobilizations as current manifestations of a larger, long-standing American "countermovement" against post1968 conservatism.

Theda Skocpol is Victor S. Thomas Professor of Government and Sociology at Harvard University, and Director of the Scholars Strategy Network.
Overview chapters by the editors, along with framing chapters penned by Doug McAdam and by Jacob Hacker, argue that right-wing U.S. politics in our era fuses racially tinged social activism with Republican Party politics, and contend that a similar synthesis of social movement building and party politics is happening on the left. Today's resistance, these chapters claim, uneasily marries mainstream efforts to preserve core U.S. institutions from an authoritarian Trump White House with much more radical movements opposing what their leaders see as a patriarchal, racist, capitalist "system" that Donald Trump epitomizes but did not create.

Social movement theory frames this volume, a genre of analysis focused on broad sociocultural tendencies and civil society organizations more than just on electoral politics. Born in sociology and also elaborated by leading political scientists like Tarrow, social movement analysis as currently practiced is often criticized as left leaning. In some ways, that is a fair characterization of this volume, whose contributors present anti-Trump efforts from the point of view of "progressive" national organizers and sometimes downplay discordant facts. For instance, at various points, contributors suggest that Bernie Sanders activists have been especially prominent in the anti-Trump resistance. Yet available evidence suggests that most resisters emerged, starting in late 2016, from the Hillary Clinton campaign — not necessarily from its professional ranks but from grassroots networks of Hillary volunteers all over the country. ${ }^{1}$ By now, many observers have documented that most participants in anti-Trump resistance efforts are white females, college educated, and middle-aged or older. ${ }^{2}$ But demography is not all that matters, because these white middle-class resisters abhor the racist and intolerant Trump provocations that appeal to (even thrill) other Americans who are likewise mostly middle-class whites. The Trump wars racking the country right now are in important respects a civil war between opposed camps of white Americans-camps whose 
participants have very divergent understandings of the trajectory and meaning of U.S. history.

For social movement analysts, it is awkward to acknowledge the prominence in the anti-Trump resistance of middle-class white females, including moderates. Such theorists tend to presume that progressive politics is (and should be) led by young people and persons of color with leftist views. That expectation may be the reason this collection of essays spends many pages discussing such pre-2016 leftist manifestations as Occupy Wall Street and Black Lives Matter, as well as preexisting movements to fight climate change (as analyzed in Dana Fisher's chapter) and post-2005 crusades for immigrant and Latino rights (as probed in the chapter by Chris Zepeda-Millán and Sophia Wallace). Leftist proclivities aside, however, tracking pre-2016 movements into the Trump era certainly has value. As shown by Fisher's comparison of climate protestors in 2014 and 2017, this can reveal the new challenges created by the Trump presidency and begin to explore how and why movements have built broader coalitions within the wider resistance.

Along these lines, I wish the gun-control movement had been included in this volume, because it is arguably the single preexisting movement to get the biggest boosts in participation, visibility, and legislative and electoral effectiveness under Trump. My own field studies and interviews in North Carolina and Ohio reveal that women in the grassroots resistance often provided crucial behind-thescenes support to local students who staged school walkouts after the February 2018 shootings at Marjory Stoneman Douglas High School in Parkland, Florida. Similarly, media reports and scholarly studies reveal that 2018 "March for Our Lives" protests not only got backing from long-standing gun-control organizations but also attracted older females like those in other resistance efforts. ${ }^{3}$

Beyond tracking various left movements, at its core this collection spotlights newly launched anti-Trump undertakings. Marie Berry and Erica Chenoweth dissect the Women's Marches of January 2017; and Michael Dorf and Michael Chu offer a rich case study of the lawyer activists who moved from "the airport to the courtroom" to fight the Trump administration's immigrant bans. Chapters by Megan Brooker and by Hahrie Han and Michelle Oyakawa track the organizing inspired by the Indivisible Guide, published in late 2016 as an online Google Document written by former congressional staffers to help angry citizens everywhere understand how local actions could influence legislators. ${ }^{4}$ In essence, these writers explained to liberal Americans how they could imitate grassroots Tea Party tactics to fight back in localities against a president and Washington establishment they fear and despise. ${ }^{5}$ The Guide's tactical ideas spread like wildfire starting in November 2016-one of several dynamics recounted here in which Internet communication and social media enabled rapid resistance to
Trump. Various media effects are explored in David Karpf chapter. And Nancy Whittier's chapter argues that multiple modes of organizing, including electronic modalities, facilitated "intergenerational spillover," allowing resistance efforts to bring young and older protestors together to a remarkable degree.

Empirical evidence is deployed throughout The Resistance mostly to illustrate claims, rather than to test alternative possible causal hypotheses. New data include counts and demographic measures of participants in mass public protests and marches, along with some broad characterizations of people's motives and goals for joining key events. Beyond that, interviews with organizers and advocates are the chief sources, alongside media accounts of the goals and activities of many dozens of resistance organizations.

Revealing as they are, interviews with national leaders must be used with caution. For example, one of Indivisible's national founders, Angel Padilla, is quoted at length in the Brooker chapter. His comments tell us what he and his colleagues were trying to do as Indivisible moved from offering online tactical guidance to becoming, by the spring of 2017, a generously funded professional advocacy group operating from a DC headquarters. However, we cannot learn much from this interview about the activities or impact of thousands of loosely Indivisibleaffiliated grassroots groups that emerged in towns, cities, and states across America. Brooker follows national leaders in claiming that Indivisible includes some six thousand "chapters" in all congressional districts. But my research group's more detailed probing of listings on the national Indivisible map reveals that in many places, true group activity is overestimated. More importantly, careful chronological tracking shows that national organizers did not shape or direct the widespread local citizen activities that unfolded from 2016 on. $^{6}$ Local resistance groups and networks are not really chapters in bigger organizations, even though they draw ideas and resources from many national and regional sources.

Like the Tea Party outbursts that greeted Barack Obama's presidency starting in 2009, the current antiTrump resistance is in no sense any one big organization or even a loosely coordinated alliance. The Tea Party then and the anti-Trump resistance now are best conceptualized as electorally sparked movements consisting of many separate, mutually leveraging organizations, some of which are national or regional professionally directed operations, but most of which are local volunteer-led groups and informal networks. Local leaders and groups are happy to pick and choose resources and ideas offered by supralocal professionals. But national organizations cannot really control or direct the local groups, and the local groups do not have mechanisms to hold would-be national leaders accountable in any meaningful way-including when those leaders go on TV and claim to speak for the entire Tea Party or anti-Trump resistance. 
In such complex, loosely coupled protest formations, priorities can and often do diverge. Participants in local Tea Parties, for instance, often cared most about restricting immigration and "welfare programs" that help the young or minorities, while national organizations claiming to speak for "the Tea Party" pushed cuts in Social Security, Medicare, and veterans' benefits that many grassroots Tea Partiers rely upon and strongly support. ${ }^{7}$ Analogous divergences are happening in today's resistance. Grassroots people run for office and continue to organize, even as the national organizations coordinating mass Women's Marches have imploded over disputes about race and anti-Semitism. ${ }^{8}$

To give another example, as national Indivisible leaders have become increasingly enmeshed in leftist coalition building and pressure-group advocacy in Washington, D.C., they now regularly sign on to progressive manifestos and letters pushing congressional Democrats to take firm leftist stands (such as closing down government to win protections for Dreamers). ${ }^{9}$ Meanwhile, many local anti-Trump groups include citizens with views ranging from centrist to progressive; and those assembled outside of liberal metropolises or college towns rarely take hard-left stands. In 2017 and 2018, moreover, local resistance members canvassed for a wide range of Democratic candidates-including moderate centrists like Conor Lamb in southwestern Pennsylvania, Doug Jones in Alabama, and Ralph Northam in Virginia. ${ }^{10}$ In many places as well, resisters have been elected to local precinct and party committee posts with the aim of revitalizing the Democratic Party at its grassroots to welcome a broad range of new voters and causes.

This brings me to the issue of political parties-whose changing organizations, agendas, and activities are insufficiently analyzed in this book. Parties appear mostly as vehicles that express or oppose outside preferences or demands classified by demographic partisan stances. The GOP is treated as a channel for popular white racism and anti-immigrant and anti-gay prejudices. This captures one part of the social energy that has buffeted the GOP in recent years, yet ignores the equally important capture of twenty-first-century Republican governing agendas by the Koch network and other ultra-free-market elites pushing unpopular goals. Such elite capture, in turn, helped weaken the institutional GOP to the point that it could not parry an outside takeover by a reality TV, ethnonationalist demagogue in 2015-16. ${ }^{11}$

On the other side, the Democratic Party is little discussed except as an "establishment" that resists progressive advocates. Of course, this volume had to be put to bed months before a tsunami of female Democratic candidates, many of them resisters or backed by volunteer resistance networks, swept into local, state, and congressional offices in the 2018 midterm elections. ${ }^{12}$ Most of these chapters were also written prior to the most recent shifts in Democratic Party stands and activities, especially in key states like Pennsylvania or Wisconsin. But the tendency of social movement theorists to pit "insider" politics against "outside" popular pressure is also at work in painting the Democratic Party out of the picture. Most authors in the Resistance collection seem to assume that street protests and marches are radical and transformative, while elections and party activities are establishment business as usual. To see how misleading such assumptions can be, we need only remember the impact on Republican candidates and officeholders of the grassroots Tea Party mobilizations that gathered steam after the 2008 election of the nation's first African American president. ${ }^{13}$

Although not pursued in this collection, one obvious way to get more precise empirical and analytical leverage on the current anti-Trump resistance is to probe similarities and differences with Tea Party reverberations in party politics and governance. This left-right comparison makes a lot more sense than comparisons of the anti-Trump resistance to Occupy Wall Street or leftist movements. Just eight years apart, the Tea Party and anti-Trump mobilizations were similarly set off by the election of a controversial president, along with copartisan congressional majorities. That kind of conjuncture frightens and mobilizes partisans on the other side. But exactly how and to what effect have these two electorally sparked movements unfolded? And will their impacts on parties and electoral fortunes unfold along parallel or different lines?

To answer such questions, researchers must avoid "outside versus inside" distinctions and explore the complex, shifting interplay of citizen organizing, party politics, federated election outcomes, and revamped governing agendas. Above all, they must take into account differences between the Republican and Democratic Parties at the times these contentious explosions emerged in their surroundings-because the Tea Party's impact on an already internally weakened GOP after 2008 has surely proved more radicalizing and disorganizing than the impact, so far, of anti-Trump resistance efforts on the Democratic Party. During 2017, the anti-Trump resistance led the way in building widespread popular understanding and support for the Affordable Care Act, something elected Democrats had not managed to do over the eight previous years, yet which helped propel Democratic candidates into office in $2018 .{ }^{14}$ And there are many signs, especially at local and state levels, that participants in today's anti-Trump civic resistance are running for office and moving into Democratic Party organizations and campaigns, buoying Democratic clout and broadening its appeal as a counter to the Trump-era GOP. There are many Tea Party parallels. Yet the current resistance is not simply a left-progressive movement, and it is unlikely to push Democrats as far to the left, either economically or racially, as grassroots Tea Partiers have pushed the GOP toward the ethno-nationalist right. 
Contributors to this provocative and pioneering volume have done an excellent job of setting the table for further, deeper research on the anti-Trump resistance and its effects— but their chapters are only a beginning. Much more remains to be done by these scholars and others to fully grasp the many parts of the anti-Trump resistance and their likely reverberations in American politics for years to come.

\section{Notes}

1 Gose and Skocpol 2018.

2 In addition to pp. 236-37 in Chapter 11 by Hahrie Han and Michelle Oyakawa in The Resistance, see additional data on the demography of grassroots resistance participants in Gose and Skocpol 2018; Putnam and Skocpol 2018; Shulevitz 2017; Tesfaye 2017; and Zernike 2018.

3 See Grinberg 2018 and especially Fisher 2018. Fisher's sampling of the Washington, DC, March for Our Lives participants on March 24, 2018, shows that seven in 10 were women, mostly college educated and averaging 49 years of age. Not just youthful gun victims, but also their mothers are often featured in this movement's public narratives. As Kristin Goss (2008) has argued, the U.S. gun-control movement has long been disproportionately female, and this is not the first time the authority of mothers and motherhood has been invoked. A larger hypothesis worth further testing is that today's anti-Trump resistance has had positive spillover effects for prior civic efforts of many kinds disproportionately led and supported by American women.

4 Bethea 2016; Levin et al. 2016.

5 Levin, Greenberg, and Padilla 2017.

6 Gose and Skocpol 2018.

7 Parker and Barreto 2014; Skocpol and Williamson 2012.

8 Kauffman 2018; Kucinich 2018; Peterson 2018; and Silva 2018.

9 Everett 2018; Weber 2018.

10 Bethea 2017; Franke-Ruta 2018; Kim 2018; Putnam 2018; Putnam and Skocpol 2018; and Lewis-Kraus 2017.

11 Skocpol and Hertel-Fernandez 2016.

12 Conroy 2018; Sievin 2018; Wilson 2018.

13 Skocpol and Williamson 2012, chapter 5.

14 Nilsen and Scott 2019; Weigel 2017.

\section{References}

Bethea, Charles. 2016. "The Crowdsourced Guide to Fighting Trump's Agenda." The New Yorker, December 16, 2016.

. 2017. "How the Trump Resistance Went Pro in Alabama." The New Yorker, December 15, 2017.
Conroy, Meredith. 2018. "At Least 123 Women Will Be in the Next Congress. Just 19 Are Republicans."

FiveThirtyEight, November 16, 2018.

Everett, Burgess. 2018. "Liberal Groups Push Dem Leaders to Take Harder Line in Shutdown Talks." Politico, December 28, 2018. (Includes link to December 28 letter sent by dozens of groups, including Indivisible to Democratic leaders Chuck Schumer and Nancy Pelosi.)

Fisher, Dana. 2018. "Here's Who Actually Attended the March for Our Lives. (No, It Wasn't Mostly Young People." Monkey Cage, March 28, 2018.

Franke-Ruta, Garance. 2018. "The Resistance Is Organized and Ready in District Where Trump Is Visiting." Yahoo News, January 18, 2018.

Gose, Leah and Theda Skocpol. 2018. "Resist, Persist, and Transform: The Emergence and Impact of Grassroots Resistance Groups in the Early Trump Presidency." Paper presented at the Annual Meeting of the American Sociological Association, Philadelphia, August 13, 2018. (Revised version under journal review).

Goss, Kristin A. 2008. Disarmed: The Missing Movement for Gun Control in America. Princeton: Princeton University Press.

Grinberg, Emanuella. 2018. "How the Parkland Students Pulled Off a Massive National Protest in Only 5

Weeks." CNN, March 26, 2018.

Kauffman, L. A. 2018. "First They Marched, Then They Mobilized: How the Resistance Swayed the Midterms." The Guardian, November 11, 2018.

Kim, Victoria. 2018. "These Orange County Supermoms Weren't Very Politically Active. Now They're a Major Force Fighting Trump in the Midterm Election." Los Angeles Times, 30 October 2018.

Kucinich, Jackie. 2018. "A Record Number of Women Were Just Elected, but the Women's March Is Imploding." The Daily Beast, November 19, 2018.

Levin, Ezra, et al. 2016. Indivisible: A Practical Guide for Resisting the Trump Agenda. Initially posted as a Google document, December 14, 2016.

Levin, Ezra, Leah Greenberg, and Angel Padilla. 2017. "To Stop Trump, Democrats Can Learn from the Tea Party." New York Times, 31 January 2017.

Lewis-Kraus, Gideon. 2017. "How the Resistance Helped Democrats Dominate Virginia." New York Times, 13 November 2017.

Nilsen, Elia and Dylan Scott. 2019. "The Silent Majority of Democratic House Freshmen.” Vox, January 27, 2019.

Parker, Christopher S. and Matthew A. Barreto. 2013. Change They Can't Believe In: The Tea Party and Reactionary Politics in America. Princeton: Princeton University Press.

Petersen, Anne Helen. 2018. "Women Built the Beto Campaign in Texas-So Where Are the Men?" BuzzFeed News, November 6, 2018. 
Putnam, Lara. 2018. "Who Really Won PA 18?" Democracy: A Journal of Ideas, March 15, 2018.

Putnam, Lara and Theda Skocpol. 2018. "Middle America Reboots Democracy." Democracy: A Journal of Ideas 49(Summer): 51-61.

Shulevitz, Judith. 2017. "Year One: Resistance Research." NYR Daily (the New York Review of Books), November 9, 2017.

Sievin, Peter. 2018. "Anti-Trump Protests Gave Way to Local Fervor That Helped Turn Wisconsin Back to Blue." Washington Post, 23 November 2018.

Silva, Daniella. 2018. "Women's March in California Cancelled over Concerns It Would Be 'Overwhelmingly White." NBC News, December $31,2018$.

Skocpol, Theda and Alexander Hertel-Fernandez. 2016. "The Koch Network and Republican Party Extremism." Perspectives on Politics 14(3): 681-99.
Skocpol, Theda and Vanessa Williamson. 2012. The Tea Party and the Remaking of Republican Conservatism. New York: Oxford University Press.

Tesfaye, Sophia. 2017. "White Women Strike Back: The Demographic That Gave Us Trump Seeks Redemption." Salon, November 9, 2017.

Weber, Joseph. 2018. "Schumer Bashed by Left over Shutdown-Ending Deal.” Fox News, January 23, 2018. (Includes link to January 22, 2018, statement from national Indivisible leaders.)

Weigel, David. 2017. "Left Out of the AHCA Fight, Democrats Let Their Grassroots Lead-and Win." Washington Post, 24 March 2017.

Wilson, Reid. 2018. "Women Set New Record in State Legislatures." The Hill, November 15, 2018.

Zernike, Kate. 2018. "The Year of Women's Activism: Marches, Phone Banks, Postcards, More." New York Times, 3 November 2018. 